\title{
Time-dependent effect of composted tannery sludge on the chemical and microbial properties of soil
}

\author{
Ricardo Silva de Sousa ${ }^{1}$ Vilma Maria Santos ${ }^{1}$ Wanderley Jose de Melo ${ }^{2}$. \\ Luis Alfredo Pinheiro Leal Nunes ${ }^{1}$ Paul J. van den Brink ${ }^{3,4}$. \\ Ademir Sérgio Ferreira Araújo ${ }^{1}$
}

Accepted: 19 September 2017 / Published online: 3 October 2017

(C) Springer Science+Business Media, LLC 2017

\begin{abstract}
Composting has been suggested as an efficient method for tannery sludge recycling before its application to the soil. However, the application of composted tannery sludge (CTS) should be monitored to evaluate its effect on the chemical and microbial properties of soil. This study evaluated the time-dependent effect of CTS on the chemical and microbial properties of soil. CTS was applied at $0,2.5$, 5,10 , and $20 \mathrm{Mg} \mathrm{ha}^{-1}$ and the soil chemical and microbial properties were evaluated at $0,45,75,150$, and 180 days. Increased CTS rates increased the levels of $\mathrm{Ca}, \mathrm{Cr}$, and $\mathrm{Mg}$. While Soil $\mathrm{pH}$, organic $\mathrm{C}$, and $\mathrm{P}$ increased with the CTS rates initially, this effect decreased over time. Soil microbial biomass, respiration, metabolic quotient, and dehydrogenase increased with the application of CTS, but decreased over time. Analysis of the Principal Response Curve showed a significant effect of CTS rate on the chemical and microbial properties of the soil over time. The weight of each variable indicated that all soil properties, except $\beta$-glucosidase, dehydrogenase and microbial
\end{abstract}

Electronic supplementary material The online version of this article (https://doi.org/10.1007/s10646-017-1861-9) contains supplementary material, which is available to authorized users.

Ademir Sérgio Ferreira Araújo

asfaruaj@yahoo.com.br

1 Soil Quality Lab., Agricultural Science Center, Federal University of Piauí, Teresina, PI, Brazil

2 Department of Technology, Sao Paulo State University, Jaboticabal, Brasil University, Descalvado, SP, Brazil

3 Wageningen Environmental Research (Alterra), Wageningen, The Netherlands

4 Aquatic Ecology and Water Quality Management Group, Wageningen University, Wageningen, The Netherlands quotient, increased due to the CTS application. However, the highest weights were found for $\mathrm{Cr}, \mathrm{pH}, \mathrm{Ca}, \mathrm{P}$, phosphatase and total organic C. The application of CTS in the soil changed the chemical and microbial properties over time, indicating $\mathrm{Cr}, \mathrm{pH}, \mathrm{Ca}$, phosphatase, and soil respiration as the more responsive chemical and microbial variables by CTS application.

Keywords Ecotoxicology $\cdot$ Waste management $\cdot$ Soil properties $\cdot$ Soil pollution

\section{Introduction}

Industrialization has increased the generation of solid wastes in developed and developing countries (Singh et al. 2011). The main problem is that disposal of solid waste in the environment leads to environmental pollution (Vergara and Tchobanoglous 2012). To avoid or mitigate environmental pollution, it is important to select appropriate alternative methods for solid waste management other than landfilling (Araujo et al. 2010). Agricultural utilization of solid wastes is one of the most promising and cost effective options of disposal (Crecchio et al. 2004; Hargreaves et al. 2008; Araujo et al. 2010). In the tannery industry, a large amount of solid waste is produced in the form of tannery sludge (TS). However, TS contains organic matter and some inorganic compounds, such as chromium $(\mathrm{Cr})$, salts, carbonates, and hydroxides (Araujo et al. 2015), which means that it may be inappropriate for use in agriculture unless treated. TS can be safe for agricultural purposes by a process of detoxifying the contaminants present in the sludge. Therefore, it is necessary to find suitable methods 
Table 1 Chemical attributes of the CTS used in the experiment

\begin{tabular}{lllllllllllllll}
\hline $\mathrm{pH}$ & Moisture & $\mathrm{TOC}$ & $\mathrm{N}$ & $\mathrm{P}$ & $\mathrm{K}$ & $\mathrm{Ca}$ & $\mathrm{Mg}$ & $\mathrm{Na}$ & $\mathrm{S}$ & $\mathrm{Cu}$ & $\mathrm{Ni}$ & $\mathrm{Cd}$ & $\mathrm{Cr}$ & $\mathrm{Pb}$ \\
\hline $\mathrm{H}_{2} \mathrm{O}$ & $\%$ & $--------------------\mathrm{g} \mathrm{kg}^{-1}$ & ----------------- & & $--------\mathrm{mg} \mathrm{kg}^{-1}$ & & & \\
7.5 & 68 & 201 & 15 & 4.9 & 2.9 & 121 & 7.2 & 49.1 & 10 & 16 & 23 & 1.9 & 1943 & 40 \\
$\mathrm{MLP}^{\mathrm{a}}$ & - & - & - & - & - & - & - & - & - & 200 & 70 & 3 & 150 & 180 \\
\hline
\end{tabular}

${ }^{a}$ Maximum limit permitted by Brazilian regulation (CONAMA 2009) for TS recycling and detoxification before its application in agriculture.

Among several methods available for TS detoxification, composting has been reported as a useful and efficient method (Santos et al. 2011; Silva et al. 2014; Araujo et al. 2015), and may help contribute towards the reduction of solid waste disposal in the environment. The use of composted solid waste is increasing in agricultural areas (Madrid et al. 2007) since the compost can improve organic matter content and fertility of the soil (Yuksel 2015). Although the use of composted solid wastes with high amounts of organic matter and some chemical elements, such as $\mathrm{P}, \mathrm{K}$, and $\mathrm{Ca}$, may improve soil fertility (Anikwe and Nwobodo 2002), consecutive application of these wastes may promote the accumulation of metals in soil and cause soil pollution (Pérez et al. 2007). Additionally, the process of composting is not totally efficient during detoxification of TS, and the application of composted tannery sludge (CTS) to the soil should be monitored to mitigate possible negative effects on soil chemical and microbial properties.

The chemical properties of soil are important indicators of soil fertility as well as soil pollution. On the one hand, the use of composted solid wastes with high amounts of organic matter and some chemical elements, such as $\mathrm{P}, \mathrm{K}$, and $\mathrm{Ca}$, may improve soil fertility (Anikwe and Nwobodo 2002). On the other hand, consecutive application of these wastes may promote the accumulation of metals in soil and cause soil pollution (Pérez et al. 2007). Similarly, the microbial properties of soil are important as they regulate several environmental processes in the ecosystem (Lavelle and Spain 2001). Soil microorganisms, as the drivers of the microbial processes, represent a large fraction of global terrestrial biodiversity and act in many important soil processes, including decomposition of organic matter and nutrient cycling (Condron et al. 2010). Additionally, soil microbial biomass and its biochemical processes, which are mediated by enzymes, are early and sensitive indicators of soil pollution after waste management (Santos et al. 2011; Silva et al. 2014; Patel and Patra 2014).

Currently, the response of the chemical and microbial properties of soil to composted solid waste is unclear and can vary with the type of waste applied (Ahlberg et al. 2006; Roca-Perez et al. 2009; Araujo et al. 2015). The use of composted solid waste can improve the chemical properties of the soil, but can also increase the accumulation of metals (Garcia-Gil et al. 2000; Roca-Perez et al. 2009). Microbial properties of soil have also shown both positive and negative responses to compost application (Crecchio et al. 2004; Ros et al. 2006; Pérez et al. 2007; Scherer et al. 2011), which are influenced by differences in the composition of the compost, mainly its content of inorganic compounds, such as metals. Also, studies on the timedependent effect of tannery sludge have focused on the untreated waste and, therefore, it is still unclear what the effect of composted tannery sludge is on chemical and microbial properties.

As composted tannery sludge contains a high content of organic matter, chromium, salts, carbonates, and hydroxides, its consecutive application, in long-term, could change both the chemical and microbial properties of the soil. Our hypothesis was that the application of CTS will, in the long term, change the chemical properties of the soil and influence the soil microbial properties over time. Therefore, the aim of this study was to evaluate the time-dependent effect of CTS on the chemical and microbial properties of a tropical soil.

\section{Materials and methods}

The experimental site is located at the Long-Term Experimental Field of the Agricultural Science Center, Federal University of Piauí, Piaui, Brazil. The soil of the area is classified as a Fluvisol with the following composition at 0-20-cm depth: $10 \%$ clay, $28 \%$ silt, and $62 \%$ sand.

CTS was produced by mixing tannery sludge with sugarcane straw and cattle manure (ratio 1:3:1; v:v:v) and the composting was performed using the aerated-pile method for 90 days. The physicochemical characteristics of CTS (Table 1) were evaluated at the end of the composting process. The water content was determined after oven drying the samples at $105^{\circ} \mathrm{C}$ for $24 \mathrm{~h}$, the $\mathrm{pH}$ was directly read, and total solids were measured by drying the samples at $65^{\circ} \mathrm{C}$ (APHA 2005). The total organic C content was evaluated by dichromate oxidation of the samples under external heating (Nelson and Sommers 1996). The total $\mathrm{N}$ content was determined using the Kjeldahl method 
after sulphuric acid digestion of the samples (Bremner 1996). The total $\mathrm{Ca}, \mathrm{Mg}, \mathrm{K}, \mathrm{P}, \mathrm{S}, \mathrm{Na}, \mathrm{Zn}, \mathrm{Cu}, \mathrm{Cd}, \mathrm{Pb}, \mathrm{Ni}$, and $\mathrm{Cr}$ concentrations were determined by atomic absorption spectrophotometry after nitric acid digestion of the samples in a microwave oven (USEPA 1996).

The experiment started in 2009 with annual application of CTS at five rates: 0 (without CTS application), 2.5, 5, 10, and $20 \mathrm{Mg} \mathrm{ha}^{-1}$ of CTS (dry basis). From 2009 to 2014, cowpea was cultivated annually in a completely randomized design with four replicates. Plots are $20 \mathrm{~m}^{2}$ each, with $12 \mathrm{~m}^{2}$ of usable area for soil and plant sampling, and rows are spaced $1.0 \mathrm{~m}$ apart. In the 7th year (2015), CTS was applied 10 days before maize (Zea mays L.) AG 1051 sowing. The CTS was spread on the soil surface and incorporated into the 20-cm layer with a harrow. Maize was grown at a density of 5 plants $\mathrm{m}^{-1}$ (approximately 62,000 plants ha ${ }^{-1}$ ) for 75 days. After this period, cowpea [Vigna unguiculata (L.) Walp.], cv. BRS Tumucumaque, was sowed at the density of 6 plants $\mathrm{m}^{-1}$ (approximately 120,000 plants $\mathrm{ha}^{-1}$ ) for 68 days. The plants were grown under rainfed conditions. The timeline of the experiment is shown in Fig. 1.

In order to measure the time-dependent effect of CTS on soil chemical and microbial properties, soil samples were collected from January to June, 2015, from each plot at 0 , 45, 75 (during maize growth), 150 and 180 (during cowpea growth) days after CTS application. For soil sampling, four soil samples were collected in each plot $(0-20 \mathrm{~cm})$, sieved (2-mm), and stored at $4{ }^{\circ} \mathrm{C}$ prior to analysis. Before the analysis, the soil was pre-incubated for 7 days with a moisture content adjusted to $60-70 \%$ of the water-holding capacity to equilibrate the physiological activity of soil microbial biomass (Brookes and Joergensen 2006).

The $\mathrm{C}$ levels of the soil microbial biomass (MBC) were determined by the microwave irradiation extraction method

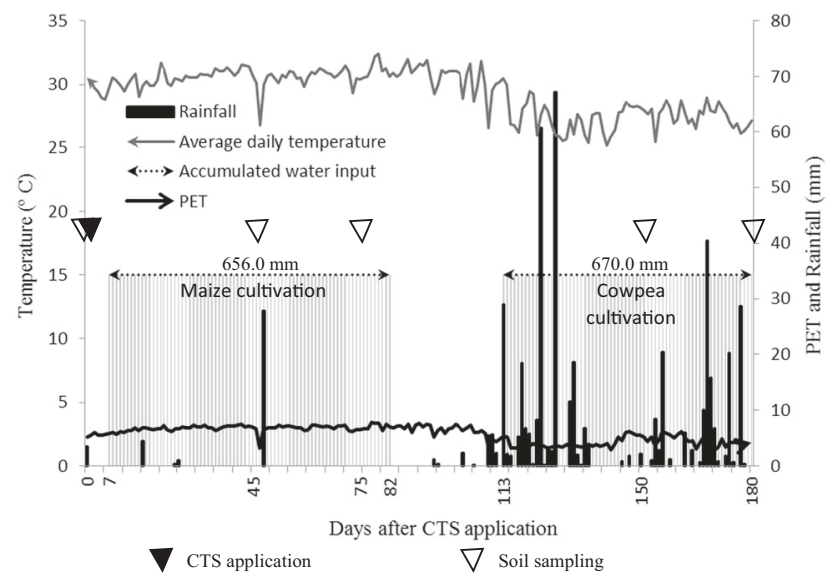

Fig. 1 Timeline of the experiment (climatic data, CTS application, soil sampling, maize and cowpea cultivation, input of water). PET potential evapotranspiration
(Islam and Weil 1998; Ferreira et al. 1999). Briefly, $25 \mathrm{~g}$ fresh soil were irradiated for $2 \mathrm{~min}$. in a microwave. The remaining $25 \mathrm{~g}$ fresh soil were non-irradiated and treated as control. Irradiated and non-irradiated soils were extracted with $100 \mathrm{~mL} 0.5 \mathrm{~mol} \mathrm{~L}^{-1} \mathrm{~K}_{2} \mathrm{SO}_{4}$ (soil:extractant = 1:4) and shaken for $30 \mathrm{~min}$ on a shaker. An extraction efficiency coefficient of 0.21 was used to convert the difference in soluble $\mathrm{C}$ between irradiated and non-irradiated soils in MBC. Soil respiration (SR) was monitored with a daily measurement of $\mathrm{CO}_{2}$ evolution under aerobic incubation at $25^{\circ} \mathrm{C}$ for 7 days (Alef and Nannipieri 1995). The metabolic quotient $\left(\mathrm{qCO}_{2}\right)$ was calculated from the ratio between SR and $\mathrm{MBC}$ and is expressed as $\mathrm{mg} \mathrm{CO}_{2} \mathrm{~kg}^{-1} \mathrm{MBC}$ day ${ }^{-1}$ (Anderson and Domsch 1993). The microbial quotient (qmic) was calculated as the ratio of MBC to total organic carbon, expressed as percentage (\%). Dehydrogenase (DHA) activity was determined according to Casida et al. (1965), based on the spectrophotometric analysis of triphenyl tetrazolium formazan released by $5 \mathrm{~g}$ of soil after $24 \mathrm{~h}$ of incubation at $35^{\circ} \mathrm{C}$. Phosphatase (PHO) activity involved the colorimetric estimation of the p-nitrophenol released after $1 \mathrm{~h}$ of incubation at $37^{\circ} \mathrm{C}$ (Tabatabai and Bremner 1969). $\beta$-glucosidase (GLY) activity was measured according to the method described by Eivazi and Tabatabai (1988).

The soil samples for chemical analysis were air dried and sieved (2-mm). Soil $\mathrm{pH}$, exchangeable $\mathrm{Ca}^{2+}, \mathrm{Mg}^{2+}, \mathrm{K}^{+}$and $\mathrm{Na}^{+}$, and the available $\mathrm{P}$ were estimated according to EMBRAPA (1997). Soil electric conductivity (EC) was evaluated in water $(1: 2 ; \mathrm{v}: \mathrm{v})$ according to the method described by Richards (1954). Total organic C (TOC) was determined by wet combustion using a mixture of $5 \mathrm{~mL}$ of $0.167 \mathrm{~mol} \mathrm{~L}^{-1}$ potassium dichromate and $7.5 \mathrm{~mL}$ of concentrated sulfuric acid under heating $\left(170{ }^{\circ} \mathrm{C}\right.$ for $\left.30 \mathrm{~min}\right)$ (Yeomans and Bremner 1988).

Microbiological data were evaluated with univariate statistical analysis (ANOVA), considering the CTS rates, sampling time and the interactions, through $\mathrm{R}$ software $(\mathrm{R}$ Core Team 2016). For this analysis, SR data were converted into $\log (\mathrm{X})$.

We used Principal Response Curve (PRC) (Van den Brink and Ter Braak 1998, 1999) to evaluate temporal changes in microbiological and chemical properties caused by different doses of CTS as compared with those in the control (CTS-free soil), and also to quantify the contribution of each property to separate the treatments from the control. The PRC method is a multivariate technique based on the redundancy analysis ordination technique and was performed using CANOCO (version 5) (Ter Braak and Smilauer 2012). The PRC diagram shows the difference in the composition of the microbiological and chemical properties of the treatments compared to the controls as they develop over time. This technique was specifically developed for 
analyzing microcosm experiment data (Van den Brink and Ter Braak 1998, 1999). The results of the PRC analysis can also be evaluated in terms of the fraction of the variance, that is explained by the factors' time and treatment. Only the fraction that is explained by treatment is shown in the PRC diagram. To assess the statistical significance of the effects of the treatments on the composition of the microbiological and chemical properties a Monte Carlo permutation test was performed together with the redundancy analysis. Monte Carlo permutation of the plots was used to test the significance of the PRC diagram in terms of displayed treatment variance, by using an $\mathrm{F}$ type test statistically based on the eigenvalue of the component (Van den Brink and Ter Braak 1999). For each sampling day Monte Carlo permutation tests were conducted by testing the replicates of each treatment against those of the controls separately, to access the significance of the treatment effects for each sample date. Within all analyses, the values of the microbiological and chemical properties were centered and standardized.

\section{Results}

\section{Soil chemical properties}

CTS rates and sampling times had a significant influence on the chemical properties of the soil, except the $\mathrm{K}$ content. Only the $\mathrm{pH}$ values were significantly influenced by the interaction between CTS rates and sampling time (Table 2). The average of chemical properties in unamended soil $(0$ $\left.\mathrm{Mg} \mathrm{ha}^{-1}\right)$ and in amended soil with CTS $(2.5,5,10$, and 20 $\mathrm{Mg} \mathrm{ha}^{-1}$ ) are shown in Table S1. Soil $\mathrm{pH}$ increased with increasing CTS rates (Fig. 2a), and the values were

Table 2 ANOVA of the effect of CTS rates $(0,2.5,5,10$ and $20 \mathrm{Mg}$ $\left.\mathrm{ha}^{-1}\right)$ and sampling time $(0,45,75,150$, and 180 days $)$ on soil chemical properties

\begin{tabular}{llll}
\hline $\begin{array}{l}\text { Chemical } \\
\text { attributes }\end{array}$ & F-values & & \\
\cline { 2 - 4 } & CTS rate & sampling time & $\begin{array}{l}\text { CTS dose } \times \\
\text { sampling time }\end{array}$ \\
\hline $\mathrm{pH}$ & $204.711^{* *}$ & $50.392^{* *}$ & $2.022^{*}$ \\
$\mathrm{EC}$ & $6.339 * *$ & $44.685^{* *}$ & 0.572 \\
$\mathrm{TOC}$ & $7.927 * *$ & $20.543 * *$ & 1.069 \\
$\mathrm{P}$ & $12.596^{* *}$ & $22.939^{* *}$ & 0.0003 \\
$\mathrm{Ca}$ & $15.054^{* *}$ & $14.720^{* *}$ & 1.470 \\
$\mathrm{Cr}$ & $299.69^{* *}$ & $6.63 * *$ & $15.87 * *$ \\
$\mathrm{~K}$ & 0.448 & $52.502^{* *}$ & 0.908 \\
$\mathrm{Mg}$ & $4.755^{*}$ & $16.301 * *$ & 0.631 \\
$\mathrm{Na}$ & $3.538^{*}$ & $36.180^{* *}$ & 0.690 \\
\hline
\end{tabular}

$E C$ electrical conductivity, TOC total organic carbon

$* P<0.05, * * P<0.01$ significant at the highest rates of CTS. The EC values showed a similar pattern than those observed for $\mathrm{pH}$ over time (Fig. 2b), but significant effects of CTS rates were only observed at 45 and 75 days. TOC and P content increased with increasing CTS rates, showing the highest values in the application $20 \mathrm{Mg} \mathrm{ha}^{-1} \mathrm{CTS}$. However, the results show a decrease in TOC and $\mathrm{P}$ at the end of experiment (Fig. 2c, d). The values of $\mathrm{Ca}, \mathrm{Cr}$, and $\mathrm{Mg}$ increased significantly with the CTS rates (Fig. 3). Over time, $\mathrm{Ca}$ and $\mathrm{Mg}$ did not vary (Fig. 3a, c), while $\mathrm{Cr}$ decreased significantly between 45 and 70 days at the highest CTS rate (Fig. 3b). The values of $\mathrm{Na}$ increased between 0 and 45 days and then did not vary over time (Fig. 3d).

\section{Soil microbial properties}

CTS rates, sampling time and their interaction had a significant influence on soil microbial properties, except for the CTS rates on the $\beta$-glucosidase activity, and the interaction of CTS and sampling time on dehydrogenase activity (Table 3). The average of microbial properties in unamended soil $\left(0 \mathrm{Mg} \mathrm{ha}^{-1}\right)$ and in amended soil with CTS $\left(2.5,5,10\right.$, and $\left.20 \mathrm{Mg} \mathrm{ha}^{-1}\right)$ are shown in Table S2.

Initially, soil MBC increased with the application of CTS and this increase varied between 45 and 75 days (Fig. 4a). Therefore, the results showed that in the low rate treatments (2.5 and $5 \mathrm{Mg} \mathrm{ha}^{-1}$ ) the MBC increased up to 75 days, while in the high rate treatments $\left(10\right.$ and $\left.20 \mathrm{Mg} \mathrm{ha}^{-1}\right)$ the values of MBC increased up to 45 days. Afterward, the values of MBC decreased showing the largest decrease at 10 and $20 \mathrm{Mgha}^{-1} \mathrm{CTS}$. Soil respiration showed similar pattern found for MBC over time (Fig. 4b). However, the values showed lower variation in the treatments with $0,2.5$ and $5 \mathrm{Mg} \mathrm{ha}^{-1}$ than in the 10 and $20 \mathrm{Mg} \mathrm{ha}^{-1}$ CTS.

The values of $\mathrm{qCO}_{2}$ increased significantly in the plots that received the application of CTS (Fig. 4c); however, the greatest increase was found in soil amended with $20 \mathrm{Mg}$ $\mathrm{ha}^{-1}$ CTS. In contrast, the values of qmic presented similar pattern those observed for MBC, showing an increase up to 75 days, in low CTS rates ( 2.5 and $5 \mathrm{Mg} \mathrm{ha}^{-1}$ ); in high rates (10 and $20 \mathrm{Mg} \mathrm{ha}^{-1}$ ) the values increased up to 45 days (Fig. 4d).

The results of the enzyme activity assays showed a different trend. Considering the pattern of responses over time, $\beta$-glucosidase and phosphatase were higher showed an increase up to 45 days, while dehydrogenase increased up to 75 days after CTS application (Fig. 5). However, phosphatase increased while dehydrogenase decreased as a result of the CTS treatments. $\beta$-glucosidase did not respond to the CTS rates (Fig. 5, Table 3). 

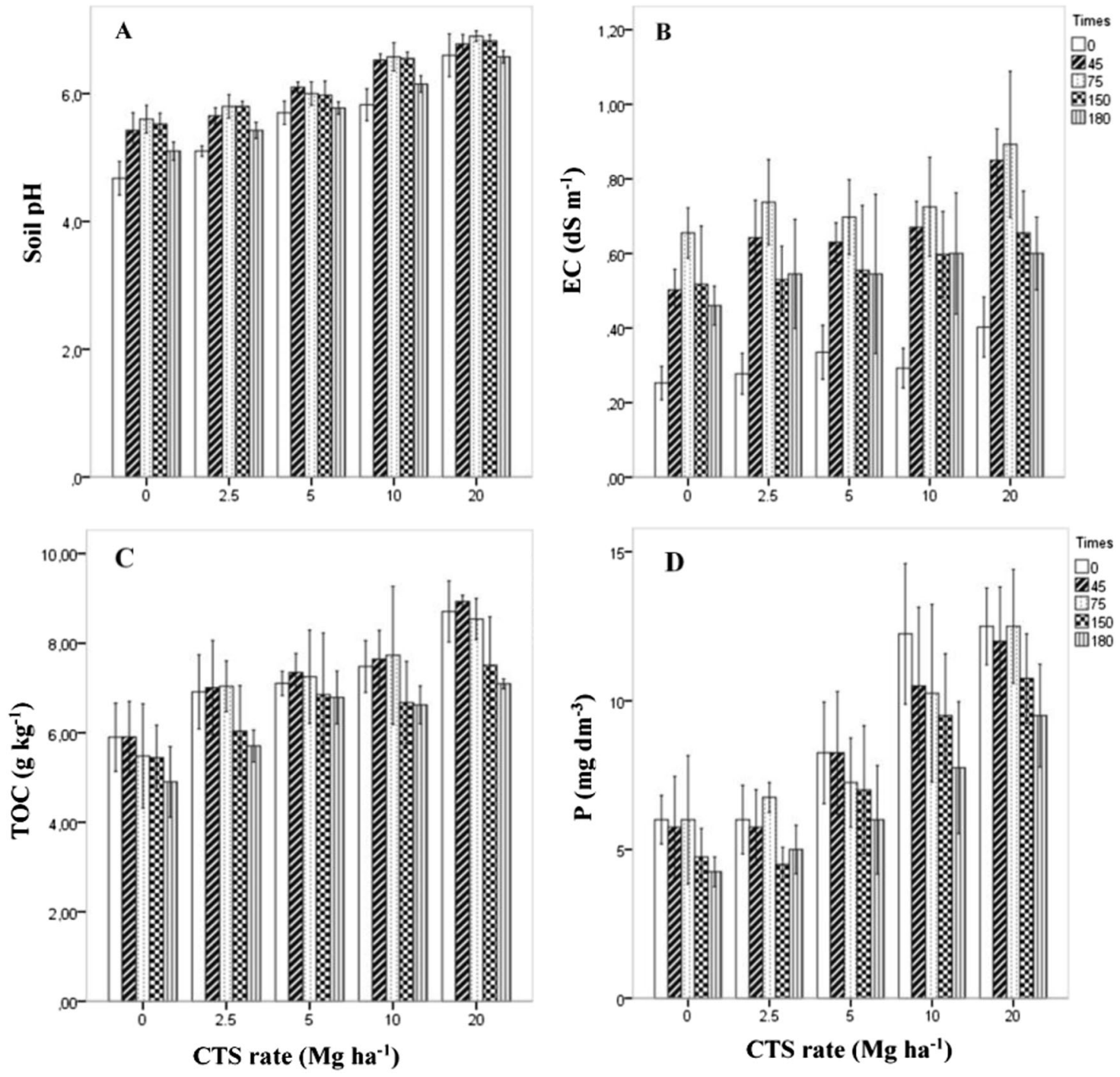

Fig. 2 Soil pH (a), electric conductivity-EC (b), total organic carbon-TOC (c) and phosphorus-P (d) in soil samples of unamended soil $\left(0 \mathrm{Mg}\right.$ ha $\left.{ }^{-1}\right)$ and in amended soil with CTS $\left(2.5,5,10\right.$, and $\left.20 \mathrm{Mg} \mathrm{ha}^{-1}\right)$ during 180 days. Bars indicate the standard deviation

\section{Time-dependent effect of CTS on soil properties}

The PRC analysis showed a significant effect $(P<0.001)$ of CTS rate on the chemical and microbial properties of the soil over time (Fig. 6). Of the variance, 39\% could be attributed to sampling date; this is displayed on the horizontal axis. Treatment contributed to $40 \%$ of the variance, and the remaining variance $(21 \%)$ was between-replicate variation. Of the treatment variance, $76 \%$ is displayed on the vertical axis of the first PRC (Fig. 6). The second PRC only explained $7 \%$ and is, therefore, not shown. The weight $\left(b_{k}\right)$ of each variable indicated that all soil properties, except $\beta$-glucosidase, dehydrogenase and microbial quotient, increased due to the CTS application. However, the highest weights $\left(b_{k}\right)$ were found for $\mathrm{Cr}, \mathrm{pH}, \mathrm{Ca}, \mathrm{P}, \mathrm{PHO}$ and TOC, indicating that these properties were the most responsive to CTS application. The results also showed that, over time, the treatments were significantly different from the controls (Monte Carlo permutation tests, $P=0.023$ ).

\section{Discussion}

The application of CTS changed the chemical properties of the soil due to the chemical composition of the CTS, which had high $\mathrm{pH}$, organic $\mathrm{C}, \mathrm{Ca}, \mathrm{Na}$, and $\mathrm{Cr}$ contents (Table 1). Our results show that the chemical properties increased with CTS rates at time zero, and can be attributed to consecutive application of CTS over the seven-year experimental period. Generally, the application of CTS increased the organic matter and the nutrient content of the soil, including $\mathrm{P}, \mathrm{Ca}$, and Mg. Thus, CTS application was important for improving soil fertility and plant growth. However, increases in soil $\mathrm{pH}$, salinity, and $\mathrm{Cr}$ accumulation can 

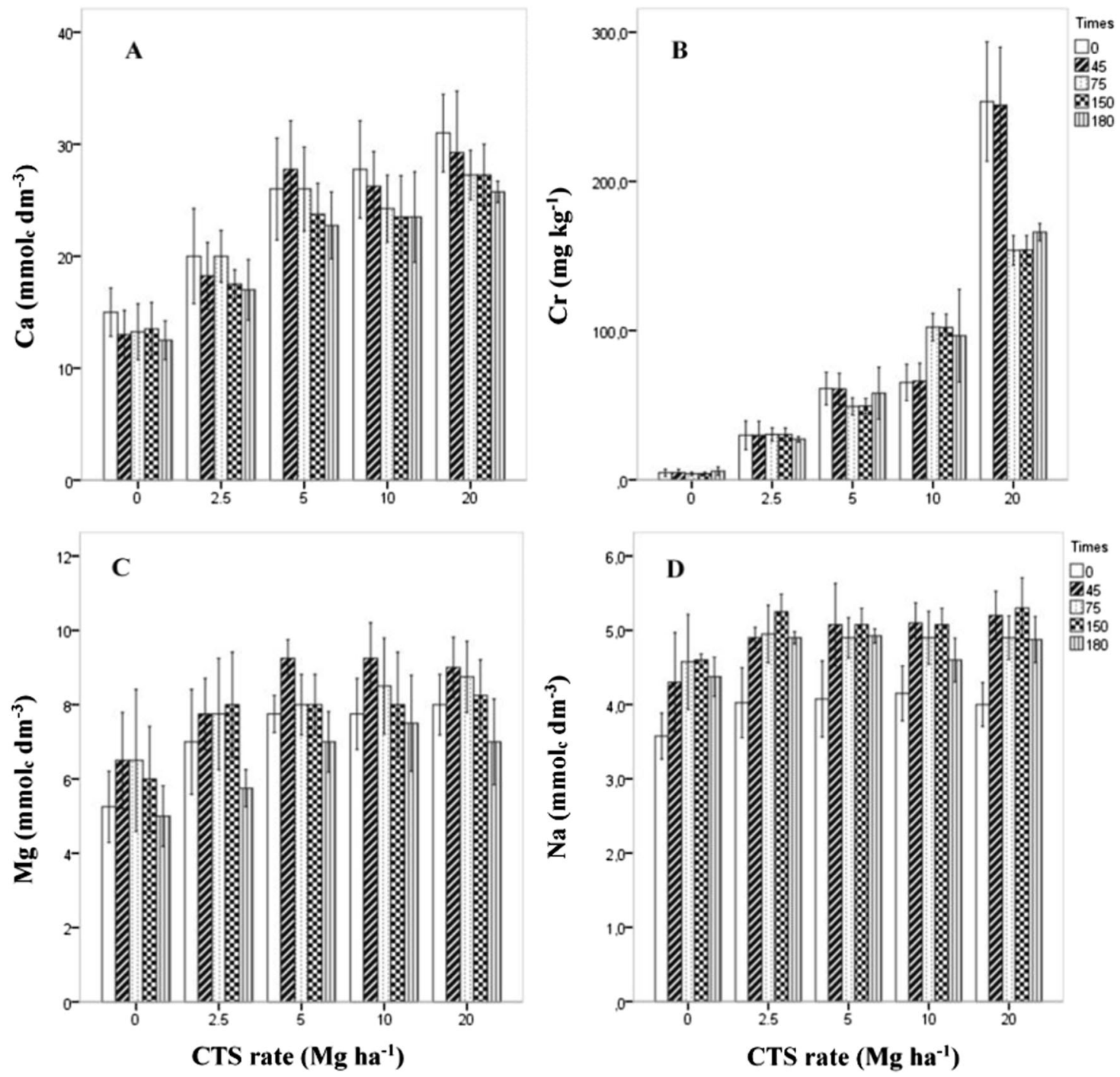

Fig. 3 Calcium-Ca (a), chromium-Cr (b), magnesium-Mg (c) and sodium- $\mathrm{Na}(\mathbf{d})$ in soil samples of unamended soil $\left(0 \mathrm{Mg}^{-1}\right)$ and in amended soil with CTS $\left(2.5,5,10\right.$, and $\left.20 \mathrm{Mg} \mathrm{ha}^{-1}\right)$ during 180 days. Bars indicate the standard deviation

Table 3 ANOVA of the effect of CTS rates $(0,2.5,5,10$ and $20 \mathrm{Mg}$ $\left.\mathrm{ha}^{-1}\right)$ and sampling time $(0,45,75,150$, and 180 days $)$ on soil microbial properties

\begin{tabular}{llll}
\hline Microbial attributes & F-values & & \\
\cline { 2 - 4 } & CTS rate & sampling time & $\begin{array}{l}\text { CTS dose } \mathrm{x} \\
\text { sampling time }\end{array}$ \\
\hline Microbial biomass C & $3.814^{*}$ & $75.249^{* *}$ & $4.312^{* *}$ \\
Soil respiration & $62.841^{* *}$ & $96.309^{* *}$ & $10.881^{* *}$ \\
Metabolic quotient & $4.956^{*}$ & $47.807^{* *}$ & $4.531^{* *}$ \\
Microbial quotient & $3.486^{*}$ & $28.833^{* *}$ & $1.907^{*}$ \\
$\begin{array}{l}\text { Dehydrogenase } \\
\text { activity }\end{array}$ & $13.512^{* *}$ & $85.397^{* *}$ & 1.618 \\
$\begin{array}{l}\text { Phosphatase activity } \\
\beta \text {-glucosidase }\end{array}$ & $78.673^{* *}$ & $97.061^{* *}$ & $2.577^{* *}$ \\
activity & 3.251 & $823.868^{* *}$ & $3.618^{* *}$ \\
\hline
\end{tabular}

$* P<0.05, * * P<0.01$ negatively influence the microbial properties of soil (Ben Achiba et al. 2009). Despite CTS increasing the chemical properties of the soil, the values of the chemical properties generally decreased over time, which can be explained by the following: (a) the $\mathrm{pH}$ level of the soil decreased due to the release of $\mathrm{H}^{+}$from plants roots during their growth; (b) total organic $\mathrm{C}$ decreased due to the utilization of $\mathrm{C}$ by soil microbes during the experiment, as soil microorganisms use organic matter as $\mathrm{C}$ and an energy source, and; (c) $\mathrm{P}, \mathrm{Ca}$, and $\mathrm{Mg}$ decreased due to the uptake of these elements during the growth of maize and cowpea (Sousa 2016; data not shown).

Similar findings were found by Adjia et al. (2008) who evaluated the long-term effect of municipal solid waste on the chemical properties of soil and observed a decrease in the chemical parameters over time. Interestingly, there was 

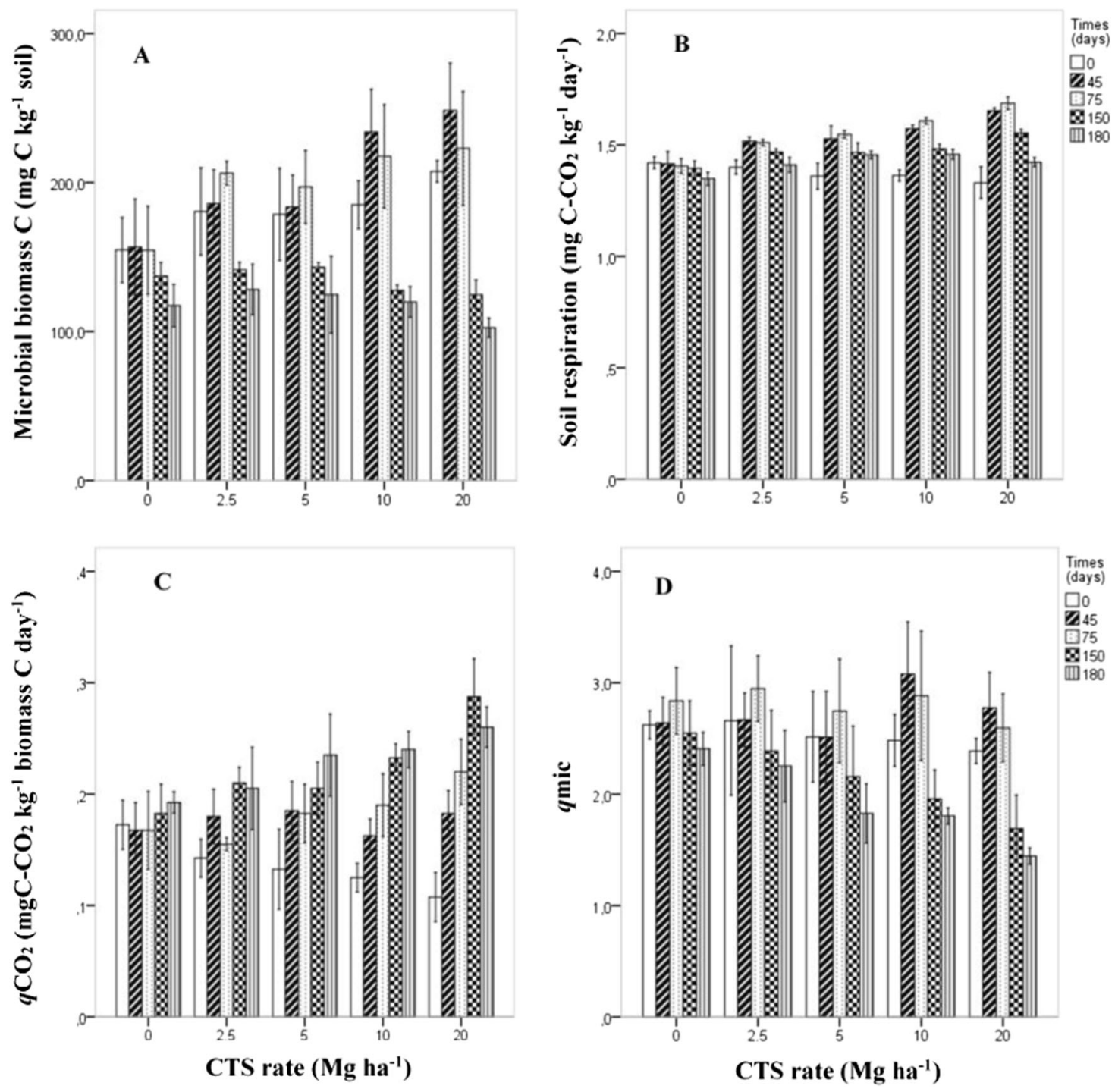

Fig. 4 Microbial biomass $\mathrm{C}(\mathbf{a})$, soil respiration (b), metabolic quotient-qCO $\mathrm{CO}_{2}$ (c) and microbial quotient-qmic (d) in soil samples of unamended soil $\left(0 \mathrm{Mg} \mathrm{ha}^{-1}\right)$ and in amended soil with CTS $\left(2.5,5,10\right.$, and $\left.20 \mathrm{Mg} \mathrm{ha}^{-1}\right)$ during 180 days. Bars indicate the standard deviation

a significant drop at the highest CTS rate in Cr concentration between day 45 and 70, and it probably occurred due to the rain event during this period which could have contributed to $\mathrm{Cr}$ percolating deeper into the soil, increasing the risk to contaminate the ground water.

The microbial properties of soil are a suitable and sensitive index for evaluation of soil disturbance after organic inputs (Ros et al. 2006) and waste application (Araujo et al. 2010). Here, we found that the response of the microbial properties of the soil to CTS application was dependent on the rate and time of exposure to the waste. Generally, the values of the microbial properties of soil increased at time zero for nearly 2 months and decreased after this time. This indicates that CTS rapidly stimulated the soil microbial properties due to the input of nutrients. Previously, Santos et al. (2011) showed in a laboratory experiment that both application rates of CTS and sampling time influenced soil microbial biomass and activity in a pattern similar to our findings under field conditions.

The short increase in soil microbial biomass and respiration after CTS application could be a response to the high input of fresh organic matter and nutrients in the CTS, which contributed to the growth and activity of the soil microorganisms (Selivanovskaya and Latypova 2006). In addition, the raw material used during the composting, such as sugarcane, straw and cattle manure, may have contributed additional $\mathrm{C}$ for increased soil microbial biomass and activity. Previous studies have shown that the application of organic waste, such as sewage (Ahlberg et al. 2006) and tannery sludge (Giacometti et al. 2012), can effectively increase soil microbial biomass. Here, the soil microbial biomass decreased 45 days $\left(10\right.$ and $20 \mathrm{Mg} \mathrm{ha}^{-1}$ ) 



Fig. 5 Enzymes activity dehydrogenase-DHA (a), phosphatase-PHO (b) and $\beta$-glucosidase (c) in soil samples of unamended soil $\left(0 \mathrm{Mg}^{-1}\right)$ and in amended soil with CTS $\left(2.5,5,10\right.$, and $\left.20 \mathrm{Mg} \mathrm{ha}^{-1}\right)$ during 180 days. Bars indicate the standard deviation

and 75 days $\left(2.5\right.$ and $\left.5 \mathrm{Mgha}^{-1}\right)$ after CTS application, which may be a result of the decomposition of organic $\mathrm{C}$ during these periods; consequently, the extra $\mathrm{C}$ and energy sources for soil microbial biomass decreased.

In our study, $\mathrm{Cr}$ was found to be an important chemical property that can be influenced the soil microbial biomass. The values of $\mathrm{Cr}$ found at the highest CTS rate $(20 \mathrm{Mg}$ $\mathrm{ha}^{-1}$ ) were higher than the maximum limit permitted by Brazilian regulation $\left(150 \mathrm{mg} \mathrm{Cr} \mathrm{kg}^{-1}\right)$. Although the $\mathrm{Cr}$ concentrations found at the highest CTS rates were significantly higher at 0 and 45 days, soil microbial biomass was also higher in this period, decreasing after 150 to 180 days. Therefore, the threshold of $\mathrm{Cr}$ concentration on microbial biomass may be higher than those permitted by Brazilian regulation. Our results disagree with Onweremadu and Nwufo (2009), which found a significant reduction of microbial biomass (41\%) in soil with $100 \mathrm{mg} \mathrm{Cr} \mathrm{kg}^{-1}$, and suggested this concentration of $\mathrm{Cr}$ is inhibitory to accumulation of microbial biomass $\mathrm{C}$. However, $\mathrm{Cr}$ must be bioavailable in soil to influence microbial biomass (Zeng et al. 2011). The bioavailability of $\mathrm{Cr}$ is controlled by adsorption characteristic of soils and it is associated with soil properties, mainly organic matter content (Krishnamurti et al. 1999). Here, the higher organic matter found in soils with application of CTS, mainly from 0 to 45 days, could have contributed to a reduction in the $\mathrm{Cr}$ bioavailability and helped maintain the microbial biomass.

This response of soil microbial biomass affected the microbial quotient (i.e., microbial biomass per unit of TOC), especially in the highly $\mathrm{Cr}$-contaminated soil that 


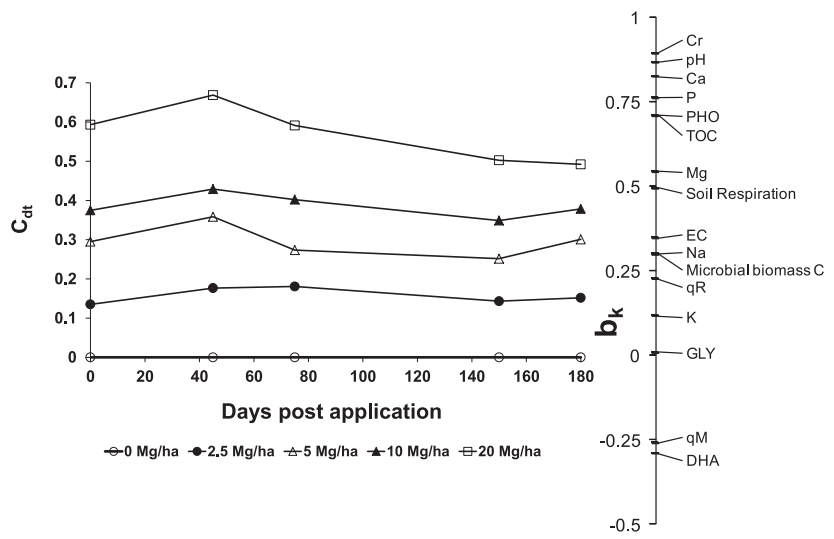

Fig. 6 Principal response curves diagram indicating the effects of the composted tannery sludge (CTS) into the soil on different soil parameters. The lines represent the course of the treatment levels in time. The weight $\left(b_{k}\right)$ can be interpreted as the affinity of the variable with the Principal Response Curves $\left(\mathrm{c}_{\mathrm{dt}}\right)$. Cr chromium, $\mathrm{pH}$ soil $\mathrm{pH}, \mathrm{Ca}$ calcium, $\mathrm{P}$ phosphorus, $\mathrm{PHO}$ phosphatase activity, TOC total organic carbon, Mg magnesium, EC electric conductivity, $\mathrm{Na}$ sodium, qR metabolic quotient, $\mathrm{K}$ potassium, GLY $\beta$-glucosidase activity, qM microbial quotient, DHA dehydrogenase activity

was receiving CTS application in high rates. In fact, as shown in the results (Fig. 3d), the values of qmic decreased and were lower than $2 \%$ at the highest CTS rates when $\mathrm{Cr}$ would be more available in the soil (between 150 and 180 days). This result agrees with Shi et al. (2002) who found qmic lower than $2 \%$ in $\mathrm{Cr}$-contaminated soils.

In contrast, soil $\mathrm{qCO}_{2}$ increased over time with CTS application and it is associated with an elevation in soil respiration and a reduction of soil microbial biomass (i.e., an indication of soil disturbance) (Wardle and Ghani 1995); this may occur when soil microbial biomass is under an unfavorable condition, such as metal-contaminated soil, and does not have the ability to physiologically cope with the stressor (Odum 1985). Specifically, a high Cr concentration may exert a higher level of stress on soil microorganisms because the microbes have a low number of resistance genes to $\mathrm{Cr}$ (Sheik et al. 2012). Thus, these results confirm that $\mathrm{Cr}$ markedly reduced the physiological ability of soil microorganisms to grow, as also reported by Sheik et al. (2012), who studied the effect of $\mathrm{Cr}$, from tannery sludge, on soil microbial communities.

The response of soil enzymes to soil pollution depends on the type of contaminant and concentration. For example, metals can inhibit the soil enzymes by interacting with enzyme- substrate complexes, denaturing the enzyme protein and interacting with its active sites (Huang et al. 2009). Also, soil enzymes exhibit a variety of responses according to their nature and characteristics. Our results showed a strong decrease in dehydrogenase activity in both unamended and amended soils with CTS over time. Dehydrogenase is an enzyme that only exists within living cells
(Dick 1994) and factors influencing active microbial biomass can affect the dehydrogenase activity. These results may be explained by the reduction in soil microbial biomass over time, which contributed to the inhibition of dehydrogenase activity. The reduction of dehydrogenase activity in the unamended soil is associated with the decrease in $\mathrm{C}$ sources to microbial biomass and also the activity of the enzyme. Considering the amended soil with CTS, the accumulation of $\mathrm{Cr}$ influenced dehydrogenase activity as this enzyme is highly sensitive to $\mathrm{Cr}$ contamination (Huang et al. 2009). Similar findings by Wyszkowska (2002) showed that at $150 \mathrm{mg} \mathrm{Cr} \mathrm{kg}^{-1}$ of soil there was a nearly complete inhibition of the dehydrogenase activity.

$\beta$-glucosidase and phosphatase are extracellular hydrolytic enzymes related to soil $\mathrm{C}$ and $\mathrm{P}$ cycle (Gil-Sotres et al. 2005). Therefore, the levels of $C$ and $P$ in the soil contribute to the $\beta$-glucosidase and phosphatase activities. We found a decrease in $\beta$-glucosidase activity during the last two time points, possibly due to the decrease in organic $\mathrm{C}$ content in all treatments. Soil microbes are able to produce and release large amounts of phosphatase (Tarafdar and Claassen 1988) and a decrease in microbial biomass would have a negative influence on phosphatase activity. Our results showed that increasing CTS concentrations increased phosphatase activity, probably in response to an increased availability of fresh substrates in the soil. This response has also been reported in previous studies where increases in phosphatase activity after application of composted solid wastes were observed (Vinhal-Freitas et al. 2010; Lakhdar et al. 2010). The decrease in phosphatase activity observed after 45 days was likely due to the reduction in soil microbial biomass in both unamended and amended soils.

The PRC analysis showed the influence of CTS application on the soil properties over time, and showed a positive correlation between the CTS rate and the response of the chemical and microbial properties of the soil. CTS application promoted different effects on the chemical and microbial properties, thereby changing the functioning of the soil ecosystem. In the PRC analysis, the weight $\left(b_{k}\right)$ of each variable was used to find the more responsive and affected variables after CTS application over time. The results indicated that $\mathrm{Cr}, \mathrm{pH}, \mathrm{Ca}, \mathrm{P}, \mathrm{PHO}$ and TOC were the most responsive properties to CTS application. Particularly, it confirms that CTS, due to its chemical composition, influences the accumulation of $\mathrm{Cr}$, the increase in soil $\mathrm{pH}$, $\mathrm{Ca}, \mathrm{P}$ and organic matter content. Although the increase in $\mathrm{Cr}$ accumulation could be harmful to soil microbial properties as discussed above, the application of CTS can supply additional nutrients, increase soil $\mathrm{pH}$, and improve the status of soil organic matter. The increase in soil $\mathrm{pH}$ and organic matter content is important to reduce the availability and mobility of $\mathrm{Cr}$ (Zeng et al. 2011). Also, the increase in the levels of organic matter improves the chemical and physical 
properties of the soil, and it is important for the plantgrowing potential of the soil, particularly for sandy soils (Gonçalves et al. 2014). For soil microbial properties, the PRC showed positive, negative or neutral responses to CTS application. Therefore, CTS did not influence $\beta$-glucosidase, but negatively affected dehydrogenase and microbial quotient. However, phosphatase, soil respiration and microbial biomass $\mathrm{C}$ were negatively affected by CTS over time. Given the magnitude of weight of the variable, these results indicate that phosphatase and soil respiration are the most sensitive microbial indicators of CTS application to the soil.

Our study showed that the long-term application of CTS could increase soil fertility and organic matter content, so improving soil quality. However, we also found a strong increase in $\mathrm{Cr}$ content after the application of CTS, and a slight increase in soil $\mathrm{pH}$ and salinity, which could have negative effects on soil microbial properties. Therefore, the application of CTS in agriculture should be carefully planned according to its chemical composition. Soil properties, mainly organic matter content, and plant species present should also be considered. Despite increasing the growth of ornamental plants (Silva et al. 2010), cowpea (Gonçalves et al. 2014) and maize (Pinheiro et al. 2015), the use of CTS on these plants can lead to accumulation of $\mathrm{Cr}$ in the shoots and grains and, therefore, should not be used on plants intended for consumption. However, because of this accumulation, these plants may be useful in the decontamination of $\mathrm{Cr}$ contaminated soils. We recommend that, before composted tannery sludge can be used as a fertilizer in agricultural soils, the treatment of the waste produced during the industrial processing of tannery sludge must be improved. In particular, a considerable reduction or elimination of the high concentrations of chromium, sodium and calcium would be necessary.

\section{Conclusions}

The application of CTS in the soil changed the chemical and microbial properties over time. The most responsive chemical properties were $\mathrm{Cr}, \mathrm{pH}, \mathrm{Ca}$, while for the microbial properties, phosphatase and soil respiration were the most responsive. CTS increased the organic matter content and nutrients of the soil, improving soil fertility and plant growth. However, the application of CTS resulted in the accumulation of chromium in the soil. Despite an initial positive affect of CTS on the soil microbial properties due to the input of fresh organic matter, over time the microbial properties were negatively affected as organic matter decreased and $\mathrm{Cr}$ availability increased. This study indicates that CTS could be applied at the lowest rates $(2.5$ and $5 \mathrm{Mg}$ $\mathrm{ha}^{-1}$ ) with permanent monitoring of the chemical and microbial properties of the soil, particularly soil microbial biomass, $\mathrm{Cr}$ accumulation, alkalinity and salinity. Increasing the organic matter content of the soil may also help to reduce the availability of $\mathrm{Cr}$ and other metals.

Acknowledgements This research was funded by "Conselho Nacional de Desenvolvimento Científico e Tecnológico" (grants 471347/2013-2; and 305102/2014-1) and "Coordenação de Aperfeiçoamento de Pessoal de Nivel Superior" (Proc. CAPES 23038.007660/ 2011-51). A.S.F Araújo is supported by a personal grant from CNPqBrazil.

\section{Compliance with ethical standards}

Conflict of interest The authors declare that they have no competing interests.

Ethical approval This article does not contain any studies with human participants or animals performed by any of the authors.

\section{References}

Ackerley DF, Barak Y, Lynch SV, Curtin J, Matin A (2006) Effect of chromate stress on Escherichia coli K-12. J Bacteriol 188:3371-3381

Adjia R, Fezeu WML, Tchatchueng JB, Sorho S, Echevarria G, Ngassoum MB (2008) Long term effect of municipal solid waste amendment on soil heavy metal content of sites used for periurban agriculture in Ngaoundere, Cameroon. African J Environ Sci Technol 2:412-421

Ahlberg O, Gustafsson P, Wedel F (2006) Leaching of metals from sewage sludge during one year and their relation to particle size. Environ Pollut 144:545-553

Alef K, Nannipieri P (1995) Methods in soil microbiology and biochemistry. Academic, New York, NY

Anderson TH, Domsch KH (1993) The metabolic quotient for $\mathrm{CO}_{2}$ $\left(\mathrm{qCO}_{2}\right)$ as a specific activity parameter to assess the effects of environmental conditions, such $\mathrm{pH}$, on the microbial biomass of forest soils. Soil Biol Biochem 25:393-395

Anikwe MAN, Nwobodo KCA (2002) Long term effect of municipal waste disposal on soil properties and productivity of site used for urban agriculture in Abakaliki, Nigeria. Biores Technol $83: 241-250$

Araujo ASF, Melo WJ, Singh RP (2010) Municipal solid waste compost amendment in agricultural soil: changes in soil microbial biomass. Rev Environ Sci Biotechnol 9:41-49

Araujo ASF, Miranda ARL, Oliveira MLJ, Santos VM, Nunes LAPL, Melo WJ (2015) Soil microbial properties after 5 years of consecutive amendment with composted tannery sludge. Environ Monit Asses 187:4153-4160

Araujo ASF, Lima LM, Santos VM, Schmidt R (2016) Repeated application of composted tannery sludge affects differently soil microbial biomass, enzymes activity, and ammonia-oxidizing organisms. Environ Sci Pollut Res 23:1-8

APHA - American Public Health Association (2005) Standard methods for the examination for water and wastewater. American Public Health Association, Washington, p 1600

Ben Achiba W, Gabteni N, Lakhdar A, Du Laing G, Verloo M, Jedidi N, Gallali T (2009) Effects of 5-year application of municipal solid waste compost on the distribution and mobility of heavy 
metals in a Tunisian calcareous soil. Agric Ecosys Environ 130:156-163

Bremner JM (1996) Nitrogen-total. In: Bigham JM (ed) Methods of soil analysis, part 3. Soil Science Society of America, American Society of Agronomy, Madison, pp 1085-1121

Brookes PC, Joergensen RG (2006) Microbial biomass measurement by fumigation-extraction. In: Bloem J, Hopkins W, Benedetti A (eds) Microbiological methods for assessing soil quality. CABI, Wallingford, pp 77-83

Casida LE, Klein DA, Santoro T (1965) Soil dehydrogenase activity. Soil Sci 98:371-376

Condron L, Stark C, O'Callaghan M, Clinton P, Huang Z (2010) The role of microbial communities in the formation and decomposition of soil organic matter. In: Dixon GR, Tilston EL (eds), Soil microbiology and sustainable crop production. Springer Science +Business Media B.V., Dordrecht, pp. 81-118

CONAMA - Conselho Nacional do Meio Ambiente (2009) Resolução $n^{\circ} 420 / 2009$, de 28 de dezembro de 2009. Diário Oficial da União, n. 249, de 30/12/2009, 81-84

Crecchio C, Curci M, Pizzigallo MD, Ricciuti P, Ruggiero P (2004) Effects of municipal solid waste compost amendments on soil enzyme activities and bacterial genetic diversity. Soil Biol Biochem 36:1595-605

Dick RP (1994) Soil enzyme activities as indicators of soil quality. In: Doran JW, Coleman DC, Bezdicek DF, Stewart BA (eds) Defining soil quality for a sustainable environment. SSSA, Madison, pp 107-124. (Special, 35)

Eivazi F, Tabatabai MA (1988) Glucosidases and galactosidases in soils. Soil Biol Biochem 20:601-606

EMBRAPA - Empresa Brasileira de Pesquisa Agropequária (1997) Manual de métodos de análise de solo. EMBRAPA, Rio de Janeiro, p 212

Ferreira AS, Camargo FAO, Vidor C (1999) Utilização de microondas na avaliação da biomassa microbiana do solo. Rev Bras Ci Solo 23:991-996

Garcia-Gil JC, Plaza C, Soler-Rovira P, Polo A (2000) Long-term effects of municipal solid waste compost application on soil enzyme activities and microbial biomass. Soil Biol Biochem 32:1907-1913

Giacometti C, Cavani L, Gioacchini P, Ciavatta C, Marzadori C (2012) Soil application of tannery land plaster, effects on nitrogen mineralization and soil biochemical properties. App Environ. Soil Sci 1:1-9

Gil-Sotres F, Trasar-Cepeda C, Leirós MC, Seoane S (2005) Different approaches to evaluating soil quality using biochemical properties. Soil Biol Biochem 37:877-887

Gonçalves ICR, Araujo ASF, Nunes LAPL, Melo WJ (2014) Soil microbial biomass after two years of consecutive application. Acta Sci Agro 36:35-41

Gough HL, Dahl AL, Nolan MA, Gaillard JF, Stahl DA (2008) Metal impacts on microbial biomass in the anoxic sediments of a contaminated lake. Journal Geophys Res 113:G02017

Hargreaves JC, Adl MS, Warman PR (2008) A review of the use of composted municipal solid waste in agriculture. Agric Ecosys Environ 123:1-4

Huang S, Peng B, Yang Z, Chai L, Zhou L (2009) Chromium accumulation, microorganism population and enzyme activities in soils around chromium-containing slag heap of steel alloy factory. Trans Nonfer Met Soc China 19:241-248

Islam KR, Weil RR (1998) Microwave irradiation of soil for routine measurement of microbial biomass carbon. Biol Fertil Soil $27: 408-416$

Jones SE, Lennon JT (2010) Dormancy contributes to the maintenance of microbial diversity. Proc Natnl Acad Sci 107:5881-5886
Krishnamurti GSR, Huang PM, Kozak LM (1999) Desorption kinetics of cadmium from soils using $\mathrm{M}$ ammonium nitrate and $\mathrm{M}$ ammonium chloride. Comm Soil Sci Pl Anal 30:2785-2800

Lakhdar A, Scelza R, Scotti R, Rao MA, Jedidi N, Gianfreda L, Abdelly C (2010) The effect of compost and sewage sludge on soil biologic activities in salt affected soil. Rev Ci Suelo Nut Veg 10:40-47

Lavelle P, Spain A (2001) Soil ecology. Kluwer Academic Publishers, Dordrecht: The Netherlands

Madrid F, López R, Cabrera F (2007) Metal accumulation in soil after application of municipal solid waste compost under intensive farming conditions. Agric Ecosys Environ 119:249-256

Nelson DW, Sommers LE (1996) Total carbon, organic carbon, and organic matter. In: Page AL (ed) Methods of soil analysis, part 2, 2nd edn. American Society of Agronomy, Madison

Odum EP (1985) Trends expected in stressed ecosystems. BioScience 35:419-422

Onweremadu EU, Nwufo MI (2009) Pedogenetic activities of soil microbes as influenced by trivalent cationic chromium. Res J Soil Biol 1:8-14

Patel A, Patra DD (2014) Influence of heavy metal rich tannery sludge on soil enzymes vis-à-vis growth of Tagetes minuta, an essential oil bearing crop. Chemosphere 112:323-332

Pérez DV, Alcantara S, Ribeiro CC, Pereira RE, Fontes GC, Wasserman MA, Venezuela TC, Meneguelli NA, Macedo JR, Barradas CAA (2007) Composted municipal waste effects on chemical properties of a Brazilian soil. Biores Technol 98:525-533

Pinheiro WG, Araujo ASF, Oliveira MLJ, Araujo FF, Melo WJ (2015) Residual effect of composted tannery sludge on yield and $\mathrm{Cr}$ content in green corn. Científica 43:37-42

R Core Team (2016) R: A Language and Environment for Statistical Computing. R Foundation for Statistical Computing, Vienna, Austria

Richards LA (1954) Diagnosis and improvement of saline and alkali soils. Department of Agriculture, USDA Agricultural Handbook, 60, Washington: US, p 160

Roca-Perez L, Martinez C, Marcilia P, Boluda R (2009) Composting rice straw with sewage sludge and compost effects on the soilplant system. Chemosphere 75:781-787

Ros M, Klammer S, Knapp B, Aichberger K, Insam H (2006) Long-term effects of compost amendment of soil on functional and structural diversity and microbial activity. Soil Use Manag 22:209-218

Rosenberg W, Nierop KGJ, Knicker H, de Jager PA, Kreutzer K, Weib $T$ (2003) Liming effects on the chemical composition of the organic surface layer of a mature Norway spruce stand (Picea abies [L.] Karst.). Soil Biol Biochem 35:155-165

Santos JA, Nunes LAPL, Melo WJ, Figueiredo MBV, Singh RP, Bezerra AAC, Araújo ASF (2011) Growth, nodulation and nitrogen fixation of cowpea in soils amended with composted tannery sludge. Rev Bras Ci Solo 35:1865-1871

Scherer HW, Metker DJ, Welp G (2011) Effect of long-term organic amendments on chemical and microbial properties of a luvisol. Pl Soil Environ 57:513-518

Selivanovskaya SY, Latypova VZ (2006) Effects of composted sewage sludge on microbial biomass, activity and pine seedlings in nursery forest. Waste Manag 26:1253-1258

Sheik CS, Mitchell TW, Rizvi FZ, Rehman Y, Faisal M, Hasnain S, Krumholz LR (2012) Exposure of soil microbial communities to chromium and arsenic alters their diversity and structure. PLoS ONE 7:e40059

Shi W, Bischoff M, Turco R, Konopka A (2002) Long-term effects of Chromium and lead upon the activity of soil microbial communities. App Soil Ecol 21:169-177 
Silva MDM, Barajas-Aceves M, Araújo ASF, Araújo FF, Melo WJ (2014) Soil microbial biomass after three years of consecutive composted tannery sludge amendment. Pedosphere 24:469-475

Silva JDC, Leal TTB, Araujo ASF, Araujo RM, Gomes RLF, Melo WJ, Singh RP (2010) Effect of different tannery sludge compost amendment rates on growth, biomass accumulation and yield responses of Capsicum plants. Waste Manag 30:1976-1980

Singh RP, Singh P, Araujo ASF, Ibrahim MH, Sulaiman O (2011) Management of urban solid waste: Vermicomposting a sustainable option. Res Conservat Recycl 55:719-29

Sousa RS (2016) Soil properties and maize and cowpea development after seven years of application of composted tannery sludge. Thesis, Federal University if Piaui

Tabatabai MA, Bremner JM (1969) Use of p-nitrophenyl phosphate for assay of soil phosphatase activity. Soil Biol Biochem 1:301-307

Tarafdar JC, Claassen N (1988) Organic phosphorus-compounds as a phosphorus source for higher-plants through the activity of phosphatases produced by plant-roots and microorganisms. Biol Fertility Soils 5:308-312

Ter Braak CJF, Smilauer P (2012) Canoco reference manual and user's guide: software for ordination (Version 5.0). Microcomputer Power, Ithaca, NY, p 496

USEPA (1996) Acid digestion of sediments, sludge's and soils. Method 3050b. EPA, Washington, p 12

Van den Brink PJ, Ter Braak CJF (1998) Multivariate analysis of stress in experimental ecosystems by principal response curves and similarity analysis. Aquatic Ecol 32:163-178
Van den Brink PJ, Ter Braak CJF (1999) Principal response curves: analysis of time-dependent multivariate responses of a biological community to stress. Environ Toxicol Chem 18:138-148

Vergara SE, Tchobanoglous G (2012) Municipal solid waste and the environment: a global perspective. Ann Rev Environ Resourc 37:277-309

Vinhal-Freitas IC, Wangen DRB, Ferreira AS, Corrêa GF, Wendling B (2010) Microbial and enzymatic activity in soil after organic composting. Rev Bras Ci Solo 34:757-764

Wardle DA, Ghani A (1995) A critique of the microbial metabolic quotient $\left(\mathrm{qCO}_{2}\right)$ as a bioindicator of disturbance and ecosystem development. Soil Biol Biochem 27:1601-1610

Wyszkowska J (2002) Soil contamination by chromium and its enzymatic activity and yielding. Polish J Environ Stud 11:79-84

Whittinghill KA, Hobbie SE (2012) Effects of pH and calcium on soil organic matter dynamics in Alaskan tundra. Biogeochemistry 111:569-58

Yeomans JC, Bremner JM (1988) A rapid and precise method for routine determination of organic carbon in soil. Comm Soil Sci Pl Anal 19:1467-1476

Yuksel O (2015) Influence of municipal solid waste compost application on heavy metal content in soil. Environ Monit Assess 187:313-320

Zeng F, Ali S, Zhang H, Ouyang Y, Qiu B, Wu F, Zhang G (2011) The influence of $\mathrm{pH}$ and organic matter content in paddy soil on heavy metal availability and their uptake by rice plants. Environ Pollut 159:84-91 